\title{
INTERACTION OF VERNALIZATION, PHOTOPERIOD AND LIGHT INTENSITY IN FLORAL INITIATION OF ENDIVE")
}

\author{
J. F. HARRINGTON ${ }^{2}$ ), K. VERKERK and J. DOORENBOS \\ (Publication 190, Laboratorium voor Tuinbouwplantenteelt, \\ Landbouwhogeschool, Wageningen, The Netherlands)
}

\begin{abstract}
SUMMARY
Endive (Cichorium endivia L.) variety Fullheart No. 5 was grown under various environmental conditions to study their effect on initiation of generative growth.

Vernalization of the germinating seed or of young plants hastened floral initiation but at the expense of vegetative growth. Once vernalization has taken place, high temperature promotes bolting.

Long photoperiods hasten bolting in both vernalized and unvernalized plants. A 16-hour natural day is less effective than 8 hours of daylight followed by 8 hours of incandescent light. A limited period of short day directly after vernalization promotes floral initiation, especially when insufficient amounts of low temperature have been supplied.

Growing the plants under strong light shortened the time to floral initiation but, in contrast to the effect of vernalization and long day, it simultaneously promoted vegetative growth.
\end{abstract}

\section{InTronuction}

The experimental work done on the factors that influence induction of flowering in endive (Cichorium endivia L.) is not extensive. However, it is known that the seed can be vernalized $(3,4,5,8)$ and that subsequent flowering is promoted by long days (8). Gibberellic acid also promotes flowering (3).

The work reported in this paper consists of four separate experiments. The first was undertaken by HaRRINGTON and VerKFrR in 1954 to collect more extensive data on flowering of endive than the rather fragmentary ones published up to then. In 1957 two experiments were done which were mainly concerned with vegetative growth but yielded some data on flowering also. The fourth experiment was made in 1958 to collect additional data on the effect of an early short day treatment.

\section{Methods}

In all experiments the endive variety used was Fullheart No. 5 from Nunhem, Haelen (L.), Netherlands. In the first experiment the seed was sown on December 15, 1954 on wet filter paper, presprouted for 20 hours at $25^{\circ} \mathrm{C}$, and then vernalized at $3-5^{\circ} \mathrm{C}$ for four weeks. On January 11, 1955, unvernalized seed was presprouted, and the next day both lots of seed were sown in flats which were immediately placed under the various light treatments. On February 16 the plants were potted. The greenhouse was maintained at a temperature close to $15^{\circ} \mathrm{C}$, except that this was not possible on sunny days and later in the year when the outside temperature exceeded $15^{\circ} \mathrm{C}$.

1) Received for publication January 19, 1959.

2) Present adress: Department of Vegetable Crops, University of California, Davis, California, U.S.A. 
Three different light treatments were given: (a) an 8-hour day of natural light, (b) a 16-hour day of natural light supplemented by mercury vapor lamps during the full 16 hours, and (c) a 16-hour day, consisting of the natural day extended by weak light from 50-Watt incandescent lamps. The lamps were separated from the plants by a pane of glass one meter above them. Exhaust fans changed the air rapidly around the lamps. Thermograph records show that there were no temperature differences among the treatments at plant level.

At 6,9 and 12 weeks from sowing time a group of plants from each longday treatment was shifted to short day; simultaneously, an equal number was shifted in the opposite direction. Thus there was a total of 30 treatments, allowing the following comparisons: vernalized $v s$. unvernalized, short day vs. long day, strong-light long day vs. weak-light long day, and transferred from long day to short day or vice versa vs. never transferred. There were over 40 plants in each treatment. Harvests for fresh weight determinations $9,10 \frac{1}{2}, 12,16 \frac{1}{2}$ and 20 weeks after sowing reduced the number of plants in each treatment by 8 plants at each harvest. Thus all plants were harvested by June 1,1955 , the end of the experiment.

The second experiment was done by Verkerk and the student H. van Os. Seed was sown and vernalized in the way described for 4 weeks and sown on January 14, 1957, together with an unvernalized lot. Both lots were split into 6 groups. One of these received a 16-hour day of strong artificial light during 6 weeks; another a 9-hour short day of natural light during the same period. The other groups were shifted from long day to short day or vice versa after 2 or 4 weeks. At the conclusion of the photoperiodic treatments on March 7, 1957 all groups were split into two, half of the plants being planted in cold frames, the other half in heated frames. As mentioned above, this experiment was mainly concerned with vegetative development, but among the observations made was also the number of days between planting and bolting.

The third experiment, done by Doorenbos and the student Miss P. C. RuEMENS, was mainly concerned with leaf characters and has been described in more detail elsewhere (1). Seed was vernalized at $1^{\circ} \mathrm{C}$ during 0,2 or 4 weeks, all groups being sown on May 22, 1957. Pots were placed on lorries which were in the open from $8 \mathrm{AM}$ to $4 \mathrm{PM}$ and were then rolled into sheds where the groups subjected to long day received 8 hours of weak light from incandescent lamps, followed by 8 hours of darkness, while the groups subjected to short day were in darkness during the whole 16-hour period. One set of observations made was the date at which bolting became visible.

In the fourth experiment, unvernalized seedlings were given either an 8hour or a 16-hour day for a period of 0,4 or 8 weeks from sowing. After this they were vernalized during 0,2 or 4 weeks. Subsequent treatment was long day for all groups. Both pretreatment and after-treatment were given on the lorries described for the previous experiment. During vernalization the plants were in a room kept at $3-5^{\circ} \mathrm{C}$ and illuminated by fluorescent tubes during 8 hours daily. Seed had to be sown on three different dates, as all vernalization treatments started on July 5,1958 . Plants were observed daily for visible signs of bolting until October 1,1958 , when the experiment was discontinued. 


\section{Results}

In the course of the first experiment, numerous growing points were obtained from plants harvested at different stages under the various treatments. These growing points were dissected under a binocular microscope. No generative differentiation was ever observed at the growing point of unelongated stems. On the other hand, wherever stem elongation was apparent a generative differentiation of the apical growing point could also be observed.

The number of days between sowing and visible bolting in $50 \%$ of the plants in a group is given in Table 1 for all 30 treatments of the first experiment. These data show that all plants bolted, but that time of bolting was strongly affected by both vernalization and daylength.

Table 1 Number of days between sowing and visible bolting in $50 \%$ of plants.

\begin{tabular}{|c|c|c|}
\hline $\begin{array}{l}\begin{array}{r}\text { Temperature } \\
\text { conditions } \\
\text { conditions }\end{array} \\
\end{array}$ & Unvernalized & Vernalized \\
\hline 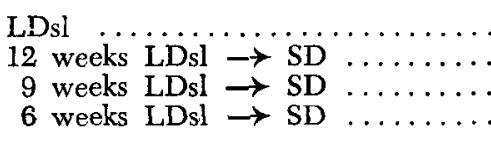 & $\begin{array}{l}79.5 \text { days } \\
79.5 \\
113.4 \\
113.8\end{array}$ & $\begin{array}{l}59.8 \text { days } \\
59.8 \\
60.5 \\
92.1\end{array}$ \\
\hline 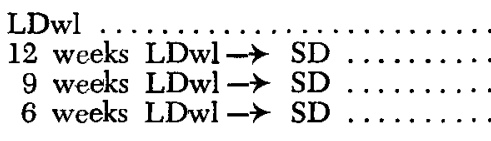 & $\begin{array}{r}78.6 \\
78.6 \\
113.8 \\
111.9\end{array}$ & $\begin{array}{r}72.6 \\
72.6 \\
73.4 \\
102.3\end{array}$ \\
\hline 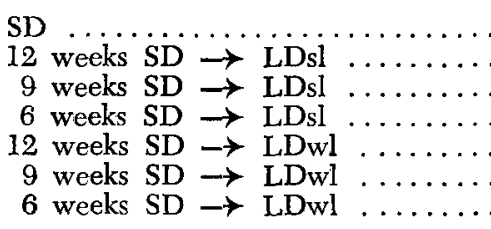 & $\begin{array}{r}112.0 \\
94.5 \\
80.2 \\
74.2 \\
94.5 \\
83.6 \\
90.3\end{array}$ & $\begin{array}{r}105.1 \\
94.5 \\
78.1 \\
67.6 \\
94.5 \\
78.9 \\
76.0\end{array}$ \\
\hline
\end{tabular}

Abbreviations : LD : long day (18 hours); SD : short day (8 hours); sl : strong light; wl : weak light.

A strong promotive effect of vernalization is apparent when one compares the figures of the second column with the corresponding ones of the third. This effect is most pronounced in plants that were in long day for a period of 9 weeks after sowing and were then transferred to short day. By contrast, in plants that were in short day for at least 9 weeks after sowing the promotive effect is small or even absent.

It was observed that the earlier was the appearance of bolting the more rapid was subsequent stem elongation. On the other hand, final stem length showed the opposite trend. For instance, the vernalized plants in continuous long day, that were the first to bolt, reached a plateau in elongation of about $50 \mathrm{~cm}$, while the unvernalized plants in continuous long day, that bolted later and more slowly, reached a plateau in stem length of about $90 \mathrm{~cm}$. In continuous short day the plants were just beginning rapid elongation at the conclusion of the experiment and had not yet reached their maximum length. The fresh weight per plant of the unvernalized groups remained significantly higher than that of the vernalized plants until about $16 \%$ weeks after sowing, 
as did the number of leaves per plant for 12 weeks. The same trend as for vernalized versus unvernalized, but not nearly as significant, was observed when long-day and short-day groups were compared.

Vernalized plants under strong light bolted and flowered earlier than those under weak light. In plants that were slower to bolt because they had not been vernalized or were retarded by a period of short day preceding the longday treatment, the effect was slight or absent. (In this connection it should be kept in mind that as the experiment progressed the natural daylight gradually became stronger). Plants under strong light that bolted earlier were also plants with the greater leaf number and the heavier fresh weight. This is the reverse of the comparisons of vernalized versus unvernalized and long day versus short day.

The data of the third experiment, summarized in Table 2, confirm the conclusion that vernalization and subsequent long days promote bolting. -

Table 2 Days from sowing to first sign of bolting in various photoperiods after different vernalization treatments.

\begin{tabular}{|c|c|c|c|}
\hline Vernalization & 8 hours & 16 hours & $\begin{array}{l}\text { Natural } \\
\text { long day }\end{array}$ \\
\hline $\begin{array}{l}0 \text { weeks } \ldots \ldots \ldots \ldots \\
2 \text { weeks } \\
4 \text { weeks }\end{array} \ldots \ldots \ldots \ldots \ldots$ & $\begin{array}{l}-1) \\
-1)\end{array}$ & $\begin{array}{l}-1) \\
51\end{array}$ & $\begin{array}{l}-{ }^{-1)} \\
43\end{array}$ \\
\hline
\end{tabular}

1) No bolting at the conclusion of the experiment 93 days after sowing.

It is of interest to note that plants subjected to 8 hours daylight +8 hours incandescent light bolted slightly in advance of those subjected to natural day. At the time of flowering the difference between the two groups had increased to 7-11 days. Natural daylength in June also reaches, and for a short period even surpasses 16 hours.

In agreement with observations made in the first experiment it was noted that plants vernalized for 4 weeks bolted more rapidly but reached a shorter stem length than those vernalized for 2 weeks. In addition it was observed that the stem of the latter was thicker, darker green and less strongly branched than that of the former, while the terminal inflorescence of the plants vernalized for 2 weeks was fasciated.

Among groups of the first experiment that were shifted from one light condition to another (Table 1) there is one that deserves further comment, viz. the unvernalized group that was shifted after 6 weeks from a short day to a long day of strong light. The plants of this group bolted after 74 days, that is 5 days before the unvernalized plants that had been in a long day of strong light continuously. In comparison with the latter, these plants also reached a maximum stem length sooner, flowered more quickly and had a smaller average plant weight and fewer leaves at any given stage of growth. This observation was confirmed in the second experiment (Table 3).

Among unvernalized plants the quickest to bolt were those subjected to 6 weeks of short day before being shifted to long day, but even plants sub- 
Table 3 Days from planting to visible bolting of vernalized and unvernalized plants in heated or unheated frames.

\begin{tabular}{|c|c|c|c|c|}
\hline \multirow[b]{2}{*}{ Photoperiod } & \multicolumn{2}{|c|}{ Unvernalized } & \multicolumn{2}{|c|}{ Vernalized } \\
\hline & $\begin{array}{l}\text { Unheated } \\
\text { frames }\end{array}$ & $\begin{array}{l}\text { Heated } \\
\text { frames }\end{array}$ & $\begin{array}{l}\text { Unheated } \\
\text { frames }\end{array}$ & $\begin{array}{l}\text { Heated } \\
\text { frames }\end{array}$ \\
\hline $\begin{array}{l}6 \text { weeks } \mathrm{SD} \ldots \ldots \ldots \ldots \\
4 \text { weeks } \mathrm{SD} \rightarrow 2 \text { weeks } \mathrm{LD} \ldots \\
2 \text { weeks } \mathrm{SD} \rightarrow 4 \text { weeks } \mathrm{LD} \ldots \\
6 \text { weeks } \mathrm{LD} \ldots \ldots \ldots \ldots \\
4 \text { weeks } \mathrm{LD} \rightarrow 2 \text { weeks } \mathrm{SD} \ldots \\
2 \text { weeks } \mathrm{LD} \rightarrow 4 \text { weeks } \mathrm{SD} \ldots\end{array}$ & $\begin{array}{l}62 \text { days } \\
60 \\
60 \\
64 \\
65 \\
63\end{array}$ & $\begin{array}{l}52 \text { days } \\
50 \\
53 \\
57 \\
56 \\
56\end{array}$ & $\begin{array}{l}49 \text { days } \\
37 \\
12 \\
12 \\
15 \\
49\end{array}$ & $\begin{array}{r}43 \text { days } \\
28 \\
9 \\
7 \\
24 \\
43\end{array}$ \\
\hline
\end{tabular}

Abbreviations : LD : long day (16 hours); SD : short day (8 hours).

jected to 6 weeks of short day followed by natural day flowered ahead of those subjected initially to 6 weeks of long day. Heating accelerated bolting but did not affect this promotive effect of an initial period of short day. In vernalized plants, however, the speed of flowering was strictly proportional to the number of long days given; there was no sign of any promotive effect of a limited period of short day after the cold treatment.

In the fourth experiment the various photoperiodic treatments were given before, not after the cold treatments. The results are given in Table 4.

Table 4 Number of days between end of cold treatment and visible bolting after various pretreatments.

\begin{tabular}{|c|c|c|c|}
\hline $\begin{array}{r}\begin{array}{r}\text { Vernalized } \\
\text { during }\end{array} \\
\end{array}$ & 0 weeks & 2 weeks & 4 weeks \\
\hline $\begin{array}{l}8 \text { weeks long day } \ldots \ldots \ldots \ldots \ldots \ldots \ldots \\
8 \text { weeks short day } \ldots \ldots \ldots \ldots \ldots \ldots \ldots \\
4 \text { weeks long day } \ldots \ldots \ldots \ldots \ldots \ldots \ldots \\
4 \text { weeks short day } \ldots \ldots \ldots \ldots \ldots \ldots \\
\text { Vernalized at germination } \ldots \ldots \ldots \ldots\end{array}$ & $\begin{array}{r}68 \\
45 \\
\left.>85^{2}\right) \\
-1) \\
-1)\end{array}$ & $\begin{aligned} & 59 \\
& 36 \\
& 65 \\
& 59 \\
> & 73^{2}\end{aligned}$ & $\begin{array}{l}39 \\
25 \\
43 \\
39 \\
50\end{array}$ \\
\hline
\end{tabular}

1) None of the plants had bolted at the conclusion of the experiment.

2) Not all plants had bolted at the conclusion of the experiment.

Here also a pretreatment in short days promoted bolting. This effect can be observed even in plants vernalized for 4 weeks, where the difference in days is smaller, but the relative difference is about as large as in unvernalized plants. A fact that deserves comment is that plants vernalized at an age of 8 weeks bolted faster than those vernalized after 4 weeks or directly after germination. As this trend is also apparent in unvernalized plants it must be concluded that the outside temperatures in May have reached values at which vernalization is possible, so that the group sown on May 10 and perhaps even that sown on June 6 received some natural vernalization. 


\section{Discussion}

Endive appears to be a plant that will initiate generative growth in time under any environmental condition that will allow plant growth to progress. However, the time from germination to bolting can be varied considerably, depending on the environment to which the plant is subjected.

The first environmental factor shown to hasten initiation of generative growth is a low temperature treatment of the germinating seed (Tables 1, 2 and 3). This is in agreement with previous work on endive $(3,4,5,8)$. A similar effect is obtained when the cold is supplied to young plants instead of germinating seed (Table 4). In both cases, the effect of low temperature on flowering is indirect, as no visible changes of the apical meristem occur during the cold treatment.

Once vernalization has taken place, high temperature promotes bolting (Table 3). In analogy to what happens in other plants (7) one would expect that a period of very high temperature $\left(30-35^{\circ} \mathrm{C}\right)$ given immediately after the cold treatment, may anull the effect of the latter. This was not investigated in the present series of experiments, however.

It is obvious from the data presented in Table 1 and 2 that long days hasten bolting in both vernalized and unvernalized plants. This had been reported previously also (8). However, the present work shows that the effect of daylength on flowering of endive is more complicated. A limited period of short day, given directly after sowing, actually induces faster generative growth than a continuous long day treatment (Table 3 and 4). One might say that such a short day treatment substitutes, to some extent, for low temperature. Such a behaviour is known from only three other plants, viz. rye, Campanula medium and Scabiosa succisa (2).

The fact that flowering occurs sooner in 8 hours of daylight supplemented by 8 hours of incandescent light than in about 16 hours of daylight (Table 2) points to an effect of wavelength. It seems reasonable to assume that the relatively large amount of near infrared radiation in the incandescent light is responsible for the promotion of bolting (6).

Light intensity must influence generative initiation in quite a different manner than daylength. Both vernalization and long day hasten bolting and flowering at the expense of rapid and total vegetative growth (see also lit. 1). High light intensity, however, simultaneously promotes bolting and causes more rapid vegetative growth than low light intensity. This may be explained by the assumption that bolting and subsequent flowering require both a certain amount of flowering stimulus (whatever its nature may be) and of energy substrate. In high light intensity, bolting is regulated by the amount of flowering stimulus, the production of which depends on vernalization and daylength. In low light intensity, insufficient photosynthesis leads to an energy limitation.

\section{LITERATURE}

I Doorenbos, J. and P. C. Riemens : Effect of vernalization and daylength on number and shape of leaves in chicory and endive. Acta Botan. Neerlandica (presented).

$2--$ and S. J. Wellensiex: Photoperiodic control of floral induction. Ann. Rev. Plant Physiol. 10, 1959 (accepted).

3 Harrington, J. F., L. Rappaport and K. J. Hood : Influence of gibberellins on stem elongation and flowering of endive. Science 125, 1957: 601-602. 
4 Meereboer, P. J. : De invloed van de temperatuur en de daglengte op het doorschieten van zomerandijvie. De Tuinbouw 2, $1947: 84-88$.

5 RAPPAPORT, L. and S. H. WITTWER: Stimulation of flowering by vernalization of endive seedlings. Proc. Am. Soc. Hort. Sci. 67, 1956 : 438-439.

6 Stolwijk, J. A. J. and J. A. D. ZeevaArt: Wavelength dependence of different light reactions governing flowering in Hyoscyamus niger. Proc. Ned. Akad. Wetensch., Amsterdam C 58, 1955: 386-396.

7 Waterschoot, H. F. : Effects of temperature and daylength on flowering in Dianthus barbatus L. Proc. Ned. Akad. Wetensch., Amsterdam C 60, 1957: 318-323.

8 WIebosch, W. A. : Changing the degree of vernalization as an aid to plant breeding (Dutch, English summ.). Meded. Direct. Tuinbouw 13, 1950: 593-607. 